OPEN ACCESS

Edited by:

Guochang $\mathrm{Hu}$,

University of Illinois at Chicago,

United States

Reviewed by:

Ivana Halova,

Institute of Molecular Genetics

(ASCR), Czechia

Nicholas A. Pullen,

University of Northern Colorado,

United States

*Correspondence:

Yong Hyun Jang

yhjang@knu.ac.kr

Seung-Yong Seo

syseo@gachon.ac.kr

Sang-Hyun Kim

shkim72@knu.ac.kr

tThese authors have contributed equally to this work

Specialty section:

This article was submitted to Inflammation,

a section of the journal

Frontiers in Immunology

Received: 08 October 2019 Accepted: 09 January 2020 Published: 28 January 2020

Citation:

Kim M-J, Je I-G, Song J, Fei X, Lee S,

Yang $H$, Kang $W$, Jang $Y H$, Seo $S-Y$ and Kim S-H (2020) SG-SP1

Suppresses Mast Cell-Mediated Allergic Inflammation via Inhibition of FCERl Signaling.

Front. Immunol. 11:50. doi: 10.3389/fimmu.2020.00050

\section{SG-SP1 Suppresses Mast Cell-Mediated Allergic Inflammation via Inhibition of Fc\&RI Signaling}

\author{
Min-Jong Kim ${ }^{1 \dagger}$, In-Gyu $\mathrm{Je}^{2 \dagger}$, Jaeyoung Song ${ }^{3+}$, Xiang $\mathrm{Fei}^{4+}$, Soyoung Lee ${ }^{5}$, \\ Huiseon Yang ${ }^{3}$, Wonku Kang ${ }^{6}$, Yong Hyun Jang ${ }^{7 *}$, Seung-Yong Seo ${ }^{4 *}$ and \\ Sang-Hyun $\mathrm{Kim}^{1 *}$
}

\begin{abstract}
${ }^{1}$ CMRI, Department of Pharmacology, School of Medicine, Kyungpook National University, Daegu, South Korea, ${ }^{2}$ Research Laboratories, ILDONG Pharmaceutical Co. Ltd., Hwaseong, South Korea, ${ }^{3}$ New Drug Development Center,

Daegu-Gyeongbuk Medical Innovation Foundation, Daegu, South Korea, ${ }^{4}$ College of Pharmacy, Gachon University, Incheon, South Korea, ${ }^{5}$ Immunoregulatory Materials Research Center, Korea Research Institute of Bioscience and Biotechnology, Jeongeup, South Korea, ${ }^{6}$ College of Pharmacy, Chung-Ang University, Seoul, South Korea, ${ }^{7}$ Department of Dermatology, School of Medicine, Kyungpook National University, Daegu, South Korea
\end{abstract}

Background: As the number of allergic disease increases, studies to identify new treatments take on new urgency. Epigallocatechin gallate (EGCG), a major component of green tea, has been shown to possess a wide range of pharmacological properties, including anti-inflammation and anti-viral infection. In previous study, gallic acid (GA), a part of EGCG, has shown anti-allergic inflammatory effect. To improve on preliminary evidence that GA has allergy mitigating effect, we designed SG-SP1 based on GA, and aimed to assess the effects of SG-SP1 on mast cell-mediated allergic inflammation using various animal and in vitro models.

Methods: For in vitro experiments, various types of IgE-stimulated mast cells (RBL-2H3: mast cell-like basophilic leukemia cells, and primary cultured peritoneal and bone marrow-derived mast cells) were used to determine the role of SG-SP1 (0.1-1 nM). Immunoglobulin (Ig) E-induced passive cutaneous anaphylaxis and ovalbumin-induced systemic anaphylaxis, standard animal models for immediate-type hypersensitivity were also used.

Results: For in vitro, SG-SP1 reduced degranulation of mast cells by down-regulating intracellular calcium levels in a concentration-dependent manner. SG-SP1 decreased expression and secretion of inflammatory cytokines in activated mast cells. This suppressive effect was associated with inhibition of the phosphorylation of Lyn, Syk and Akt, and the nuclear translocation of nuclear factor-kB. Due to the strong inhibitory effect of SG-SP1 on Lyn, the known upstream signaling to FC\&RI-dependent pathway, we confirmed the direct binding of SG-SP1 to FCERI, a high affinity IgE receptor by surface plasmon resonance experiment. Oral administration of SG-SP1 hindered allergic symptoms of both anaphylaxis models evidenced by reduction of hypothermia, serum IgE, ear thickness, and tissue pigmentation. This inhibition was mediated by the reductions in serum histamine and interleukin- 4 . 
Conclusions: We determined that SG-SP1 directly interacts with FC\&RI and propose SG-SP1 as a therapeutic candidate for mast cell-mediated allergic inflammatory disorders via inhibition of $F_{C \varepsilon R I}$ signaling.

Keywords: SG-SP1, gallic acid, mast cells, allergic inflammation, Fc\&RI

\section{INTRODUCTION}

Allergic disorders including atopic dermatitis, allergic rhinitis, asthma, food allergies, and anaphylaxis are prominent in the modern world (1). The prevalence of allergic disorders in developed countries dramatically increasing from the last decade (2). Mast cells are key players in allergic inflammation and act through the production and secretion of allergic mediators such as histamine, chemokines, cytokines, and platelet activating factor $(3,4)$. Histamine, a major factor of acute allergic responses, induces hypothermia and recruitment of leukocytes following vasodilation and an increase in vascular permeability. Inflammatory cytokines including tumor necrosis factor (TNF)$\alpha$, interleukin (IL)-1 $\beta$, IL-4, and IL-6 support a chronic phase of allergy, enhancing $\mathrm{T}$ cell activation or $\mathrm{B}$ cell survival (4). Therefore, therapeutic strategies such as glucocorticoids, anti-histamines, and non-steroidal anti-inflammatory drugs (NSAIDs) targeted mast cells to suppress allergic diseases including rhinitis and asthma (5-7).

Activation of mast cells is initiated by allergen-induced cross-linking of IgE bound by the FceRI, a high affinity IgE receptor, on the surface of cells. Fc\&RI is a heterotetrameric receptor comprised of an IgE-binding $\alpha$ subunit, the membrane tetraspanning $\beta$ subunit, and two identical disulphide linked $\gamma$ subunits (4). Assembly of the heterotetrameric structure of FceRI is initiated by the phosphorylation of the immunoreceptor tyrosine-based activating motifs on the $\beta$ and $\gamma$ subunits by Src family kinases such as Lyn and Fyn $(8,9)$. Lyn and Syk phosphorylate several adaptor molecules and enzymes to regulate mast cell activation. In addition to Lyn, FceRI aggregation activates Fyn, which phosphorylates the adaptor Gab2 to activate the PI3K pathway (4). Therefore, it would be effective to inhibit mast cell activation by binding directly to FceRI. To confirm the direct binding, surface plasmon resonance (SPR) has been used as an experimental technique. As this assay measured biomolecular interactions in a real-time manner, SPR binding analysis is mainly used to study molecular interactions (4).

We previously showed that gallic acid (GA) and its derivatives inhibited mast cell-derived allergic inflammatory reactions by blocking histamine release and pro-inflammatory cytokine expression $(10,11)$. Despite the inhibitory activity of GA

\footnotetext{
Abbreviations: Dexa, dexamethasone; DMSO, dimethyl sulfoxide; EGCG, epigallocatechin gallate; ER, endoplasmic reticulum; FceRI, the high affinity IgE receptor; GA, gallic acid; HRMS, high-resolution mass spectra; $\mathrm{IP}_{3}$, inositol 1,4,5-trisphosphate; MTT, 3-(4,5-dimethylthiazol-2-yl)-2,5-diphenyltetrazolium bromide; NSAIDs, nonsteroidal anti-inflammatory drugs; OVA, ovalbumin; PCA, passive cutaneous anaphylaxis; PE, phycoerythrin; PLC, phospholipase C; qPCR, quantitative real-time polymerase chain reaction; RBL, rat basophilic leukemia; RPMCs, rat peritoneal mast cells; BMMCs, bone marrow-derived mast cells; SNAREs, soluble $N$-ethylmaleimide attachment protein receptors.
}

on allergic inflammation, we were intrigued to design new derivatives of GA to strengthen the pharmacological effectiveness of GA. Amide and ester derivatives based on a GA scaffold for which substituent carboxylic acids and three hydroxyl groups of C3, C4, and C5 positions could be selected. Our medicinal chemistry-based efforts to modify phenol groups as well as form amides into a proper amine substituent led to the identification of compound SG-SP1, which consists of 3,4,5-trisbenzyloxyphenyl and $(S)$-phenylglycinyl groups and acts as a potent inhibitor of mast cell-mediated allergic inflammation. In the present study, we examined the anti-allergic inflammatory properties of SG-SP1 using immediate-type hypersensitivity models and elucidated the underlying inhibitory mechanism of SG-SP1 binding directly to FceRI in mast cells.

\section{MATERIALS AND METHODS}

\section{General Procedure}

All starting materials and reagents were obtained from commercial suppliers and were used without further purification. Air- and moisture-sensitive reactions were performed under an argon atmosphere. Flash column chromatography was performed with silica gel 60 (230-400 mesh, Merck KGaA, Darmstadt, Germany) and the indicated solvents. Thin-layer chromatography was performed using $0.25 \mathrm{~mm}$ silica gel plates (Merck KGaA). ${ }^{1} \mathrm{H}$ - and ${ }^{13} \mathrm{C}-\mathrm{NMR}$ spectra were recorded on a Bruker $600 \mathrm{MHz}$ spectrometer with solutions of deuteriochloroform $\left(\mathrm{CDCl}_{3}\right)$ or methanol-d4 (Cambridge Isotope Laboratory, Andover, MA). ${ }^{1} \mathrm{H}-\mathrm{NMR}$ data were reported as the order of chemical shift, multiplicity (s, singlet; $d$, doublet; $\mathrm{t}$, triplet; $\mathrm{m}$, multiplet; and/or multiple resonances), number of protons, and coupling constant $(\mathrm{J})$ in hertz $(\mathrm{Hz})$. High-resolution mass spectra (HRMS) were recorded on a JEOL JMS-700 (EI) (JEOL Ltd., Tokyo, Japan) and Agilent 6530 Q-TOF LC/MS/MS system (ESI) (Agilent Technologies, Inc., Santa Clara, CA).

\section{Synthesis of SG-SP1}

For SG-SP1, a DMF solution $(2 \mathrm{~mL})$ of $3,4,5-$ tris(benzyloxy)benzoic acid (110 mg, $0.25 \mathrm{mmol})$ was supplemented with (S)-2-phenylglycine methyl ester hydrochloride (56 mg, $0.28 \mathrm{mmol})$, EDCI (115 mg, $0.60 \mathrm{mmol}$ ), HOBt $(4.0 \mathrm{mg}, 30 \mu \mathrm{mol})$ and $\mathrm{N}, \mathrm{N}$-diisopropylethylamine (90 $\mu \mathrm{L}, 0.50 \mathrm{mmol}$ ). After stirring for $3 \mathrm{~h}$, the reaction mixture was diluted with ethyl acetate and washed with water and brine, dried over $\mathrm{MgSO}_{4}$, and concentrated on reduced pressure. The residue was purified by flash column chromatography on a silica gel (ethyl acetate $/ n$-hexane $=1: 3$ ) to produce the desired amide. Compound 3d was identified as SG-SP1 (12). 
All drug including SG-SP1, GA, and dexamethasone (Dexa) were dissolved in dimethyl sulfoxide (DMSO) and then diluted with phosphate-buffered saline (PBS). The percentage DMSO in the treated samples was maintained at $<0.5 \%$ to minimize the interference.

\section{Animals}

Imprinting Control Region (ICR) mice (male, 6 weeks, 22-25 g) and Sprague-Dawley (SD) rats (male, 10 weeks, 250-280 g) were purchased from Dae-Han Biolink (Daejeon, Republic of Korea). In many clinical studies, the incidence of systemic anaphylaxis has been shown that women are more likely to have anaphylaxis than men (13). Therefore, female animals are preferred. However, due to the size of local tissue (ear), male animals were used in this study. Throughout the study, five animals per cage were housed in a room with laminar air flow, a temperature of 22 $\pm 2^{\circ} \mathrm{C}$, and relative humidity of $55 \pm 5 \%$. Animal care and treatments were carried out in accordance with the guidelines established by the Public Health Service Policy on the Humane Care and Use of Laboratory Animals and were approved by the Institutional Animal Care and Use Committee of Kyungpook National University (IRB \#2017-0002-9).

\section{Reagents and Cell Culture}

Dexamethasone (Dexa), anti-dinitrophenyl (DNP) IgE, DNPhuman serum albumin (HSA), ovalbumin (OVA), and Histodenz were purchased from Sigma-Aldrich (St. Louis, MO), and alum adjuvant was purchased from Thermo Fisher Scientific (Waltham, MA). Rat basophilic leukemia (RBL-2H3) cells purchased from Korean Cell Line Bank (Seoul, Republic of Korea). RBL-2H3, rat peritoneal mast cells (RPMC), and mouse bone marrow-derived mast cells (mBMMC) were grown at $37^{\circ} \mathrm{C}$ in $5 \% \mathrm{CO}_{2}$ in Dulbecco's modified Eagle's medium, $\alpha$-minimum essential medium (Gibco, Grand Island, NY) and RPMI 1640 (Hyclone, Logan, UT), respectively, supplemented with $10 \%$ heat-inactivated fetal bovine serum, $100 \mathrm{U} / \mathrm{mL}$ penicillin G, $100 \mu \mathrm{g} / \mathrm{mL}$ streptomycin, and $250 \mathrm{ng} / \mathrm{mL}$ amphotericin B. In addition, complete RPMI 1640 media was supplemented by $4 \mathrm{mM}$ L-glutamine, $25 \mathrm{M}$ HEPES, $50 \mu \mathrm{M}$ 2-mercaptoethanol, $1 \mathrm{mM}$ sodium pyruvate, MEM non-essential amino acid solution (Gibco), $10 \mathrm{ng} / \mathrm{mL}$ murine IL-3, and $2 \mathrm{ng} / \mathrm{mL}$ murine SCF (PeproTech, Rocky Hill, NJ). RBL-2H3 were used throughout the study at passages ranging from 4 to 8 .

\section{Preparation of $\mathrm{mBMMCs}$}

Mouse bone marrow-derived mast cells (mBMMCs) were isolated from male ICR mouse as previously described (14). All subsequent steps were performed into the sterile cell culture hood to prevent contamination of the bone marrow. The isolated cells were grown in complete RPMI 1640 and supplemented with recombinant murine IL-3 $(10 \mathrm{ng} / \mathrm{mL})$ and stem cell factor (SCF, $2 \mathrm{ng} / \mathrm{mL}$ ) (PeproTech) for maturation during 3 weeks. After maturation, cells were seeded on the culture plates without IL-3 and SCF, sensitized with anti-DNP IgE for overnight, and then stimulated with DNP-HSA.

\section{Preparation of RPMCs}

Rat peritoneal mast cells (RPMC) were isolated from SD rats as previously described (10). The peritoneal cavity was carefully opened, and the fluid containing peritoneal cells was aspirated using a Pasteur pipette. An abdomen was massaged during washing the intestines with fluid. The mast cell preparations were approximately $95 \%$ pure, based on toluidine blue staining, and more than $97 \%$ of the cells were viable, based on trypan blue staining.

\section{Determination of Cell Viability}

Cell viability was determined by colorimetric analysis using 3-(4,5-dimethylthiazol-2-yl)-2,5-diphenyltetrazolium bromide (MTT) (15). Water-soluble MTT is converted into waterinsoluble formazan by mitochondrial dehydrogenase. RBL-2H3 $\left(3 \times 10^{4} /\right.$ well in 96 -well plates) were pretreated with various concentrations of SG-SP1 for $24 \mathrm{~h}$ and incubated with $1 \mathrm{mg} / \mathrm{mL}$ MTT at $37^{\circ} \mathrm{C}$. After $2 \mathrm{~h}$, the formazan crystals were dissolved with DMSO, and then the absorbance was measured using a spectrophotometry (Molecular Devices, Sunnyvale, CA) at a wavelength of $570 \mathrm{~nm}$. The formazan formed absorbance of untreated control was assigned as a relative value of $100 \%$.

In order to further to analyse the cell viability, cell death was detected by Annexin $\mathrm{V}$ and propidium iodide (PI) staining. Before staining, RBL-2H3 (5 $\times 10^{5}$ /well in 12-well plates) were pretreated with various concentrations of SG-SP1 for $24 \mathrm{~h}$. The cells were then washed with PBS, centrifuged, and resuspended in binding buffer $(10 \mathrm{mM}$ HEPES, $140 \mathrm{mM} \mathrm{NaCl}$, and $2.5 \mathrm{mM}$ $\mathrm{CaCl}_{2}, \mathrm{pH}$ 7.4) containing $5 \mu \mathrm{g} / \mathrm{mL}$ of Annexin $\mathrm{V}$ and PI following the manufacturer's protocol. The cells were incubated at $37^{\circ} \mathrm{C}$ in $5 \% \mathrm{CO}_{2}$ for $20 \mathrm{~min}$ and analyzed using a flow cytometer (BD Biosciences, San Diego, CA). The fluorochrome was excited using the $488 \mathrm{~nm}$ line of an argon ion laser, and emissions of Annexin V and PI were monitored at 525 and $620 \mathrm{~nm}$. A total of at least $1 \times 10^{4}$ cells was analyzed per each sample. The relative cell events of untreated control were assigned as a relative value of 1 .

\section{Determination of Mast Cell Degranulation}

To determine mast cell degranulation, levels of histamine in sera and culture media were measured. Mouse blood was centrifuged at $400 \mathrm{~g}$ for $15 \mathrm{~min}$ at $4^{\circ} \mathrm{C}$, and sera were obtained. RBL-2H3 $\left(5 \times 10^{5} /\right.$ well in 12 -well plates) were sensitized with anti-DNP $\operatorname{IgE}(50 \mathrm{ng} / \mathrm{mL})$. After incubation overnight, cells were pretreated with or without drugs for $1 \mathrm{~h}$ and then challenged on DNP-HSA $(100 \mathrm{ng} / \mathrm{mL})$ for $4 \mathrm{~h}$. mBMMCs $\left(5 \times 10^{5} /\right.$ well in 12 -well plates $)$ and RPMCs $\left(2 \times 10^{4} /\right.$ well in 24 -well plates $)$ were subjected to that same treatment as RBL-2H3; however, these were challenged on DNP-HSA for $30 \mathrm{~min}$. The cells were separated from the media by centrifugation at $150 \mathrm{~g}$ for $5 \mathrm{~min}$ at $4^{\circ} \mathrm{C}$. To separate histamine from sera and media, $0.1 \mathrm{~N} \mathrm{HCl}$ and $60 \%$ perchloric acid were added. After centrifugation, supernatants were transferred to Eppendorf tubes containing $5 \mathrm{~N} \mathrm{NaOH}, 5 \mathrm{M}$ $\mathrm{NaCl}$, and $n$-butanol, and then vortexed. The organic phase was gathered, mixed with $0.1 \mathrm{~N} \mathrm{HCl}$ and $n$-heptane, and centrifuged. The histamine in the aqueous phase was assayed using an $o$ phthaldialdehyde spectrofluorometric procedure as previously 
described (16). Fluorescence intensity was measured using a fluorescent plate reader (Molecular Devices) at an excitation wavelength of $360 \mathrm{~nm}$ and an emission wavelength of $440 \mathrm{~nm}$. Release of $\beta$-hexosaminidase is also widely used as a marker for mast cell degranulation (16). After incubation of media with $\beta$ hexosaminidase substrate buffer $(100 \mathrm{mM}$ sodium citrate, $1 \mathrm{mM}$ 4 -nitrophenyl $N$-acetyl- $\beta$-D-galactosaminide, $\mathrm{pH} 4.5$ ) for $1 \mathrm{~h}$ at $37^{\circ} \mathrm{C}$, the reaction was terminated using a stop solution $(0.1 \mathrm{M}$ $\mathrm{Na}_{2} \mathrm{CO}_{3}$ and $\mathrm{NaHCO}_{3}$ ), and the absorbance was measured using a spectrophotometry at a wavelength of $405 \mathrm{~nm}$. The percentage of $\beta$-hexosaminidase release was calculated from the equation: $[\beta$-hexosaminidase release $(\%)=$ (absorbance of supernatant $) /$ (absorbance of supernatant + absorbance of pellet $) \times 100]$.

\section{RNA Extraction and Quantitative Real-Time PCR (qPCR)}

Prior to isolation from total cellular RNA, RBL-2H3 and mBMMC $\left(5 \times 10^{5} /\right.$ well in 12 -well plates $)$ were sensitized with anti-DNP IgE (50 ng/mL). After incubation overnight, the cells were pretreated with or without drugs for $1 \mathrm{~h}$ and challenged with DNP-HSA (100 ng/mL) for $1 \mathrm{~h}$. RNAiso Plus reagent (Takara Bio Inc., Shiga, Japan) was used to extract total RNA in accordance with the manufacturer's protocol. Complementary DNA (cDNA) was synthesized from $2 \mu \mathrm{g}$ of total RNA using a Maxime RT-Pre Mix Kit (iNtRON Biotechnology, Daejeon, Republic of Korea). qPCR was carried out using a Thermal Cycler Dice TP850 (Takara Bio Inc.) according to the manufacturer's protocol. The total $25 \mu \mathrm{L}$ reaction mixture was composed of the following: 1.5 $\mu \mathrm{L}$ of cDNA (150 ng), $1 \mu \mathrm{L}$ each of the forward and reverse primers $(0.4 \mu \mathrm{M}), 12.5 \mu \mathrm{L}$ of SYBR Premix Ex Taq (Takara Bio Inc.), and $9 \mu \mathrm{L}$ of $\mathrm{dH}_{2} \mathrm{O}$. The conditions used for PCR were the same as those described previously (8). The sequences of primers are listed in Table S1. The gene expression ratio of untreated control was assigned as a relative value of 1 .

\section{Determination of Intracellular Calcium Levels}

Intracellular calcium was measured using the fluorescent indicator Fluo-3/AM (Invitrogen, Carlsbad, CA) (10). RBL-2H3 and $\mathrm{mBMMC}\left(6 \times 10^{4} /\right.$ well in 96 -well plates $)$ were sensitized with anti-DNP IgE $(50 \mathrm{ng} / \mathrm{mL})$. After incubation overnight, the cells were preincubated with Fluo-3/AM for $1 \mathrm{~h}$ at $37^{\circ} \mathrm{C}$ and washed with Tyrode's buffer $\mathrm{B}(137 \mathrm{mM} \mathrm{NaCl}, 5.5 \mathrm{mM}$ glucose, $12 \mathrm{mM} \mathrm{NaHCO}_{3}, 2.7 \mathrm{mM} \mathrm{KCl}, 0.2 \mathrm{mM} \mathrm{NaH}_{2} \mathrm{PO}_{4}, 1 \mathrm{mM} \mathrm{MgCl}_{2}$, and $1.8 \mathrm{mM} \mathrm{CaCl}_{2}$ ) to remove the dye from the cell surface. The cells were pretreated with or without drugs including SG-SP1, GA, and BAPTA-AM (Calbiochem, La Jolla, CA) for $1 \mathrm{~h}$ and then challenged on DNP-HSA (100 ng/mL). BAPTA-AM, a calcium chelator, was used as a positive control. Fluorescence intensity was detected using a fluorescent plate reader at an excitation wavelength of $485 \mathrm{~nm}$ and an emission wavelength of $510 \mathrm{~nm}$. The intracellular calcium level of untreated control was assigned as a relative value of 1 .

\section{ELISA}

The levels of inflammatory cytokines in sera and culture media were measured by ELISA (8). RBL-2H3 $\left(5 \times 10^{5} /\right.$ well in 12 well plates) were sensitized with anti-DNP IgE (50 ng/mL). After incubation overnight, the cells were pretreated with or without drugs for $1 \mathrm{~h}$ and then challenged with DNP-HSA $(100 \mathrm{ng} / \mathrm{mL})$ for $8 \mathrm{~h}$. The cells were separated from media by centrifugation at $150 \mathrm{~g}$ for $5 \mathrm{~min}$ at $4^{\circ} \mathrm{C}$. ELISA was performed on a 96-well Nunc immune plate using a commercial kit (BD Biosciences, San Diego, CA) according to the manufacturer's protocol. Before detection of OVA-specific IgE, immune plates were coated with $20 \mu \mathrm{g}$ of OVA instead of capture antibody. After terminating the reaction to a substrate, the absorbance was measured using a spectrophotometry at a wavelength of $450 \mathrm{~nm}$. The cytokine secretion ratio of untreated control was assigned as a relative value of 1 .

\section{Protein Extraction and Western Blot}

Nuclear and cytoplasmic proteins were extracted as previously described (16). Before protein extraction, RBL-2H3 $(2 \times$ $10^{6} /$ well in 6-well plates) were sensitized with anti-DNP IgE $(50 \mathrm{ng} / \mathrm{mL})$. After incubation overnight, cells were pretreated with or without drugs for $1 \mathrm{~h}$ and challenged on DNPHSA $(100 \mathrm{ng} / \mathrm{mL})$. After suspension in $100 \mu \mathrm{L}$ of cell lysis buffer A (0.5\% Triton X-100, $150 \mathrm{mM} \mathrm{NaCl}, 10 \mathrm{mM}$ HEPES, $1 \mathrm{mM}$ EDTA/ $\mathrm{Na}_{3} \mathrm{VO}_{4}, \quad 0.5 \mathrm{mM}$ PMSF/DTT, and $5 \mu \mathrm{g} / \mathrm{mL}$ leupeptin/aprotinin), the cells were vortexed, incubated for $5 \mathrm{~min}$ on ice, and centrifuged at $400 \mathrm{~g}$ for $5 \mathrm{~min}$ at $4^{\circ} \mathrm{C}$. The supernatant was collected and used as the cytoplasmic protein extract. The pellets were washed three times with $1 \mathrm{~mL}$ of PBS and then suspended in $25 \mu \mathrm{L}$ of cell lysis buffer B (25\% glycerol, $420 \mathrm{mM} \mathrm{NaCl}, 20 \mathrm{mM}$ HEPES, $1.2 \mathrm{mM}$ $\mathrm{MgCl}_{2}, 0.2 \mathrm{mM}$ EDTA, $1 \mathrm{mM} \mathrm{Na} \mathrm{VO}_{4}, 0.5 \mathrm{mM}$ PMSF/DTT, and $5 \mu \mathrm{g} / \mathrm{mL}$ leupeptin/aprotinin), vortexed, sonicated for $30 \mathrm{~s}$, incubated for $20 \mathrm{~min}$ on ice, and centrifuged at $15,000 \mathrm{~g}$ for $15 \mathrm{~min}$ at $4^{\circ} \mathrm{C}$. The supernatant was collected and used as the nuclear protein extract. Proteins were separated by 8$12 \%$ SDS-PAGE and transferred to a nitrocellulose membrane. Immunodetection was carried out using a chemiluminescent substrate (Thermo Fisher Scientific). The protein production ratio of untreated control was assigned as a relative value of 1. The following antibodies were purchased from Santa Cruz Biotech (Santa Cruz, CA); NF-кB (sc-109), ІкB $\alpha$ (sc-371), lamin B1 (sc-374015), and $\beta$-actin (sc-8432). The following antibodies were purchased from Cell Signaling Technology (Beverly, MA); phospho-Lyn (\#2731, Tyr ${ }^{507}$ ), Lyn (\#2732), phospho-Syk (\#2711, $\left.\mathrm{Tyr}^{525 / 526}\right)$, Syk (\#2712), phospho-Akt $\left(\# 9271\right.$, Ser $\left.^{473}\right)$, and Akt (\#9272). The following antibodies were purchased from Abcam (Cambridge, UK); phospho-Fyn (ab182661, Tyr ${ }^{530}$ ), and Fyn (ab125016).

\section{SPR Binding Analysis}

Physical interactions between compounds and FceRI $\alpha$ were analyzed by SPR experiment using a Biacore T200 instrument (GE Healthcare Life Sciences, Chicago, IL) FceRI $\alpha$ was immobilized on carboxylmethyl-dextran sensor chip (CM) by the amine-coupling method. FceRI $\alpha$ was diluted in $30 \mu \mathrm{g} / \mathrm{mL} \mathrm{HBS}$ EP buffer (GE Healthcare) and injected into a rate of $5 \mu \mathrm{L} / \mathrm{mL}$ for tandem immobilization on the CM5 chip surface, resulting in from 1,300 response units after stabilization. Compounds $(100 \mu \mathrm{M})$ were prepared by dilution in HBS-EP buffer at the $1 \%$ DMSO and injected into the FceRI $\alpha$ protein-coated flow channel 
at a flow of $30 \mu \mathrm{L} / \mathrm{mL}$, followed by a dissociation time for $300 \mathrm{~s}$ and a regeneration with $50 \mathrm{mM} \mathrm{NaOH}$. Raw sensorgrams were double blanked by subtracting responses from reference flow channel, a blank injection, using BiaEvaluation Software (GE Healthcare). All SPR experiments were performed at $20^{\circ} \mathrm{C}$.

\section{IgE-Mediated Passive Cutaneous Anaphylaxis}

An IgE-mediated passive cutaneous anaphylaxis (PCA) model was established as described previously (8). To induce the PCA reaction, mice were randomly divided into 7 groups $(n=$ 5/group), and the skin on the ears of mice was sensitized with an intradermal (i.d.) injection of anti-DNP $\operatorname{IgE}(0.5 \mu \mathrm{g} / \mathrm{site})$ for $48 \mathrm{~h}$. Drugs were orally administered at doses of $0.1-10 \mathrm{mg} / \mathrm{kg}$ body weight $2 \mathrm{~h}$ before intravenous (i.v.) injection of DNPHSA ( $1 \mathrm{mg} / \mathrm{mouse}$ ) and $4 \%$ Evans blue (1:1) mixture. Thirty minutes later, the mice were euthanized, and both ears were collected to measure dye pigmentation. The amount of dye was determined colorimetrically after extraction with $1 \mathrm{~mL}$ of $1 \mathrm{M} \mathrm{KOH}$ and $4 \mathrm{~mL}$ of an acetone and phosphoric acid $(5: 13)$ mixture. The absorbance of each extract was measured using a spectrophotometry at a wavelength of $620 \mathrm{~nm}$.

\section{OVA-Induced Systemic Anaphylaxis}

Mice were randomly divided into 5 groups ( $n=10$ /group) and sensitized with an OVA mixture (100 $\mu \mathrm{g}$ of OVA and $2 \mathrm{mg}$ of alum adjuvant in $200 \mu \mathrm{L}$ of PBS) by intraperitoneal (i.p.) injection on day 0 and 7. Drugs including SG-SP1, GA, and Dexa were orally administered three times at doses of $0.1-10 \mathrm{mg} / \mathrm{kg}$ body weight once every 2 days after the second sensitization. On day $14,200 \mu \mathrm{g}$ of OVA in $100 \mu \mathrm{L}$ of PBS was i.p. injected, and then rectal temperatures were measured every $10 \mathrm{~min}$ for $1 \mathrm{~h}$. After $1 \mathrm{~h}$, blood was obtained from the abdominal vein of each mouse to measure serum histamine, OVA-specific IgE, and IL-4 levels.

\section{Statistical Analysis}

Statistical analyses were performed using Prism 5 (GraphPad Software, San Diego, CA), and treatment effects were analyzed using a one-way analysis of variance followed by Dunnett's test. A value of $p<0.05$ was considered a significant difference.

\section{RESULTS}

\section{Effects of SG-SP1 on the Degranulation of Mast Cells and Expression of Inflammatory Cytokines}

The chemical structures of gallic acid (GA) and SG-SP1 were displayed in Figure 1. To rule out cytotoxic influences of SGSP1, MTT assay and Annexin V/PI staining were carried out. Up to $100 \mu \mathrm{M}$ of SG-SP1 resulted in no significant cytotoxicity after $24 \mathrm{~h}$ exposure to RBL-2H3 (Figure S1).

Mast cells are important sources of histamine, which plays a key role in allergic symptoms (17). Attenuation of mast cell degranulation could be a therapeutic strategy to regulate allergic responses. We demonstrated the influence of SG-SP1

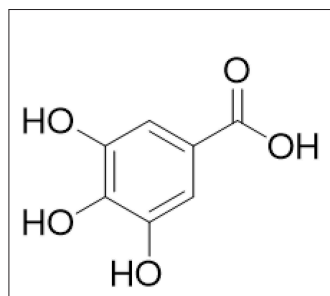

Gallic acid<smiles>COC(=O)[C@H](NC(=O)c1cc(Br)c(OCc2ccccc2)c(OCc2ccccc2)c1)c1ccccc1</smiles>

SG-SP1
FIGURE 1 | Chemical structures of gallic acid and SG-SP1. Bn, benzoyl ether

on degranulation of mast cells using RBL-2H3 (mast celllike basophilic leukemia cells) and primary cultured mast cells (RPMCs and mBMMCs). Histamine release was rapidly induced by antigen challenge and concentration-dependently suppressed by SG-SP1 treatment in all three types of mast cells. $\beta$ Hexosaminidase, another component in the mast cell granule, is also used to assay mast cell degranulation $(16,18)$. SG-SP1 similarly reduced levels of $\beta$-hexosaminidase as well as histamine (Figure 2).

Inflammatory cytokines, especially IL-4, are highly associated with allergic inflammation because of their recruitment and activation of immune cells (19). To ascertain the effects of SGSP1 on the expression of inflammatory cytokines such as TNF- $\alpha$, IL- $1 \beta$, IL- 4 and IL- 6 in RBL-2H3 and BMMCs, qPCR and ELISA were performed. The expression of these cytokines at both the mRNA and protein levels were elevated by activation of FceRI, whereas it was concentration-dependently suppressed by SGSP1 (Figure 3). For evaluation of qPCR results, we used two reference genes, $\beta$-actin and GAPDH. Gene expression ratio with two reference genes showed similar results and we showed ratio with $\beta$-actin (Figure 3A).

\section{Effects of SG-SP1 on Intracellular Calcium Levels in Mast Cells}

Calcium acts as a major secondary messenger in intracellular mast cell signaling. A rise in intracellular calcium levels was rapidly induced by antigen-IgE cross-linking, which triggered mast cell degranulation and expression of inflammatory cytokines (20). Inositol 1,4,5-trisphosphate $\left(\mathrm{IP}_{3}\right)$ generated by phospholipase $\mathrm{C}$ (PLC) $\gamma$ binds to the $\mathrm{IP}_{3}$ receptor on the endoplasmic reticulum (ER) membrane, from which calcium is released; the influx of extracellular calcium is caused by calcium depletion signaling to the ER (21). In our experiments, intracellular calcium levels were elevated to a minute of treatment for antigen challenge and were reduced by SG-SP1 (Figure 4). BAPTA-AM, a calcium chelator, was used as a positive control.

\section{Effects of SG-SP1 on the Activation of FceRI-Mediated Signaling Proteins in Mast Cells}

IgE-dependent mast cell activation leads to the secretion of three classes of mediators; degranulation results in secretion of preformed mediators that are stored in the cells' cytoplasmic 
A

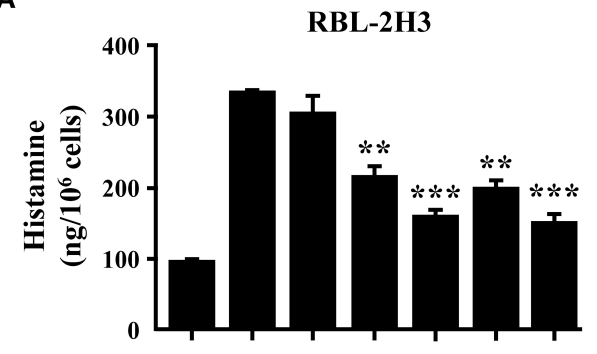

BMMCs

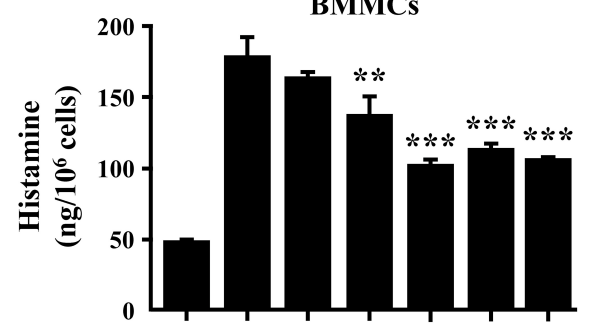

RPMCs

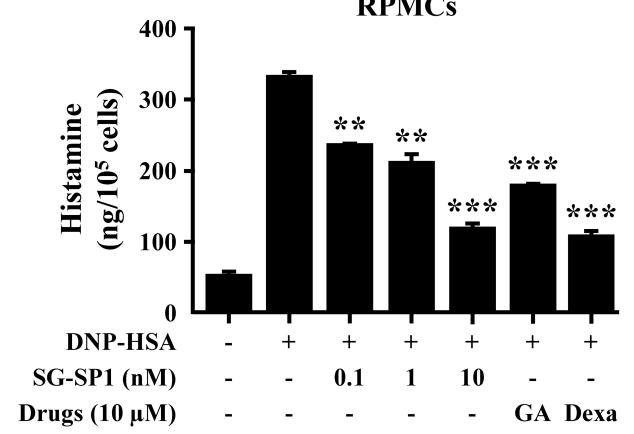

B

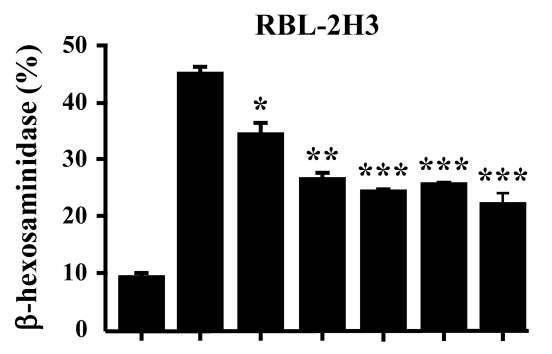

BMMCs

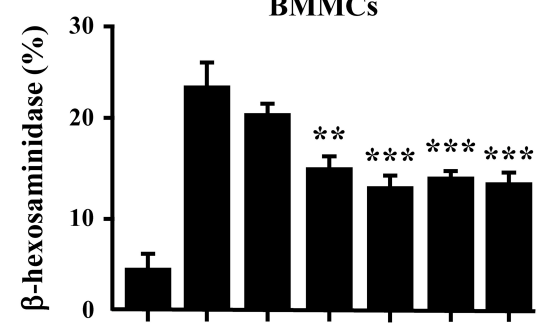

RPMCs

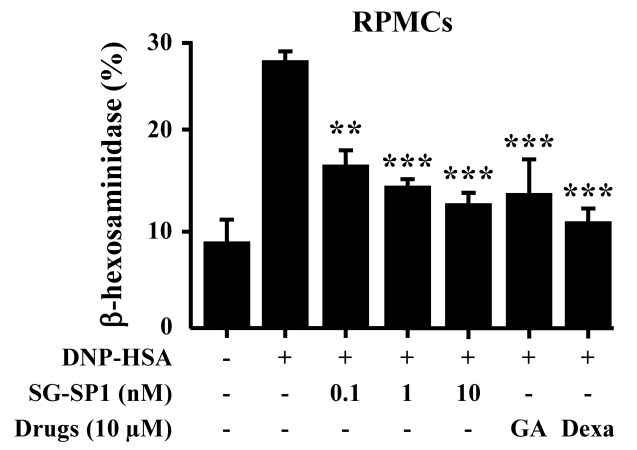

FIGURE 2 | Effects of SG-SP1 on mast cell degranulation. (A) RBL-2H3, mBMMCs ( $5 \times 10^{5} /$ well), and RPMCs (2 $\times 10^{4} /$ well) were sensitized with anti-DNP IgE $(50 \mathrm{ng} / \mathrm{mL})$. After incubation overnight, the cells were pretreated with or without drugs including SG-SP1, GA, and Dexa for $1 \mathrm{~h}$ and then challenged with DNP-HSA $(100 \mathrm{ng} / \mathrm{mL})$. Histamine levels were assayed using an o-phthaldialdehyde spectrofluorometric procedure. (B) The level of $\beta$-hexosaminidase was measured using $\beta$-hexosaminidase substrate buffer. Data were presented as the means \pm SEM of three independent experiments. ${ }^{*},{ }^{* *}$, and ${ }^{* \star \star}$ indicate statistically significant differences from the DNP-HSA-challenged group at a value of $p<0.05,0.01$, and 0.001 , respectively.

granules, pro-inflammatory lipid mediators are synthesized de novo, and growth factors, cytokines, and chemokines are synthesized and secreted (4). To determine the mechanism of SG-SP1 on suppression of expression of inflammatory cytokines and degranulation, we investigated the effects of SG-SP1 on the activation of Lyn, Syk, and Akt, representative signaling proteins in mast cells. Phosphorylations of Lyn, Fyn, and Syk (5 min), and Akt $(30 \mathrm{~min})$ were increased by DNP-HSA stimulation. We found that SG-SP1 reduced phosphorylation of Lyn, Syk, and Akt. On the contrary, SG-SP1 did not alter the phosphorylation of Fyn (Figure 5).

In addition, NF- $\kappa \mathrm{B}$ plays as a major transcription factor regulating the expression of inflammatory cytokines. NF- $\kappa \mathrm{B}$ is translocated into the nucleus following degradation of IкB $\alpha$ (22). Our results presented that $\mathrm{I} \kappa \mathrm{B} \alpha$ in the cytoplasm disappeared, whereas NF-кB in the nucleus increased after treatment with DNP-HSA. SG-SP1 inhibited NF- $\kappa$ B activation by obstructing I $\mathrm{B} \alpha$ degradation (Figure 5).

\section{Affinity Analysis of SG-SP1 to FceRl $\alpha$}

To visualize the crosslinking of IgE or SG-SP1 on FcERI $\alpha$, SPR experiment was performed. As mentioned above, IgEbinding region is $\alpha$ subunit in FceRI. For the SPR experiment, recombinant $\mathrm{Fc \varepsilon} \mathrm{RI} \alpha$ was coupled with CM5 sensor chip. Binding affinity with SG-SP1 to FcERI $\alpha$ was comparatively analyzed compared to that of IgE, a positive control. The graph shows the interactions of compounds with FceRI $\alpha$ (Figure 6). The response units obtained from the affinity analysis were elevated to both SGSP1 and IgE. The theoretical prediction of SG-SP1 as a FceRI $\alpha$ binding protein is supported by these results.

\section{Effects of SG-SP1 on Systemic and Local Anaphylaxis}

PCA is one of the most widely used animal models to demonstrate local anaphylaxis (8). After an injection of an antigen-Evans blue mixture, a single blue spot developed at the sensitized site with antigen-specific IgE because of 

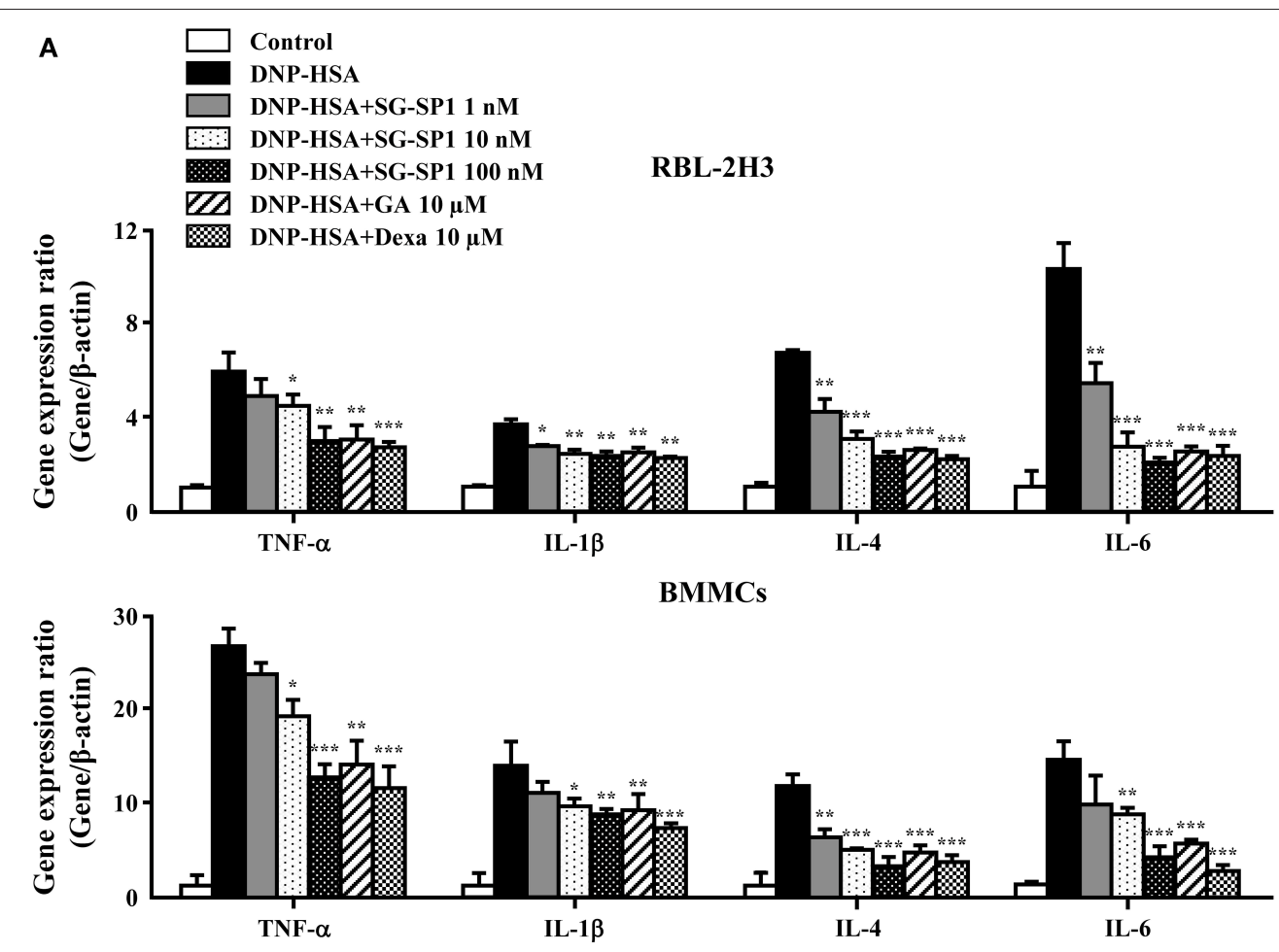

B

RBL-2H3

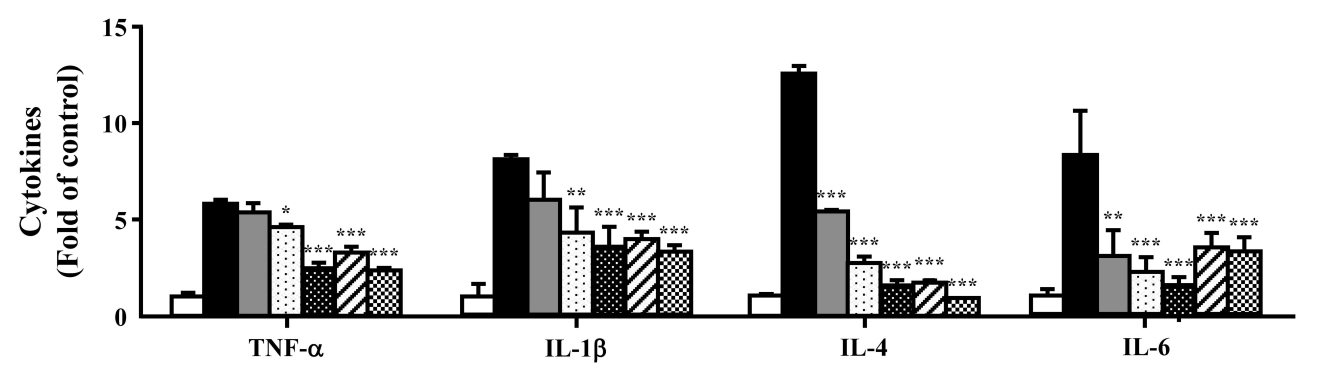

FIGURE 3 | Effects of SG-SP1 on inflammatory cytokine expression. RBL-2H3 and BMMCs were sensitized with anti-DNP IgE. After incubation overnight, the cells were pretreated with or without drugs including SG-SP1, GA, and Dexa for $1 \mathrm{~h}$ and then challenged with DNP-HSA. (A) The expression of inflammatory cytokine genes was determined by qPCR. (B) The secretion of inflammatory cytokines was measured by ELISA. Data were presented as the means \pm SEM of three independent experiments. *, ${ }^{\star *}$, and ${ }^{* \star \star}$ indicate statistically significant differences from the DNP-HSA-challenged group at a value of $p<0.05,0.01$, and 0.001 , respectively.

enhanced vascular permeability. SG-SP1 alleviated the size and lightened the color of the spot on a dose-dependent manner (Figures 7A,B). Increased vascular permeability also induced ear swelling, which was reduced by SG-SP1 (Figure 7C). To investigate the inhibitory effects of SG-SP1 on immediate-type hypersensitivity, OVA-induced systemic anaphylaxis model was adopted. This model is useful for studying anti-allergic inflammatory activities of therapeutic candidates (8). Mice sensitized with OVA mixture experience anaphylaxis after additional challenge to OVA. The rectal temperature of the mice in the vehicle group decreased over 40-50 min, whereas the serum histamine level elevated approximately 4 folds. Oral administration of SG-SP1 moderated hypothermia and reduced serum histamine release (Figures 8A,B). Serum levels of IL-4, OVA-specific IgE, and $\mathrm{IgG}_{1}$ were increased with OVA challenge and were decreased by SG-SP1 (Figures 8C-E). SG-SP1 showed more powerful suppression of both local and systemic anaphylaxis than GA did and similar inhibition in a PCA model with Dexa, a positive control drug. All animals appeared to be in healthy condition, and no abnormal symptoms were observed in body weight and food intake by SG-SP1 throughout the administration period.

\section{DISCUSSION}

Diverse environmental and genetic factors are associated with the development of allergies (1). Asthma and allergic diseases are major public health problems affecting more than 300 million people worldwide $(23,24)$. Allergies can 


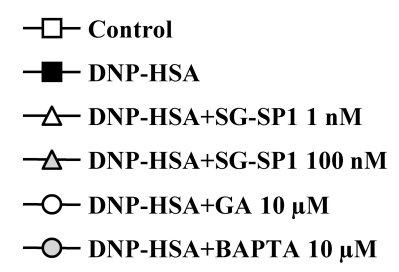

RBL-2H3
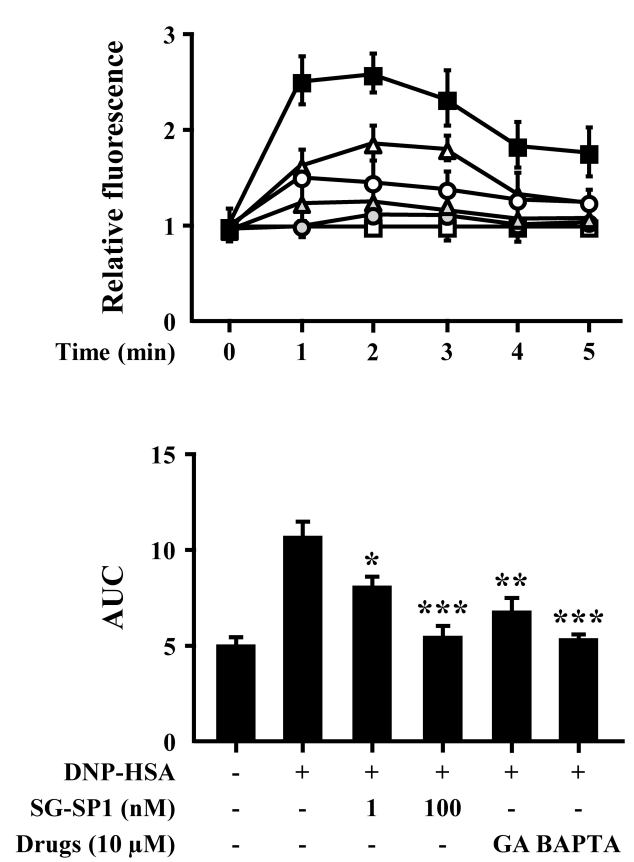

BMMCs
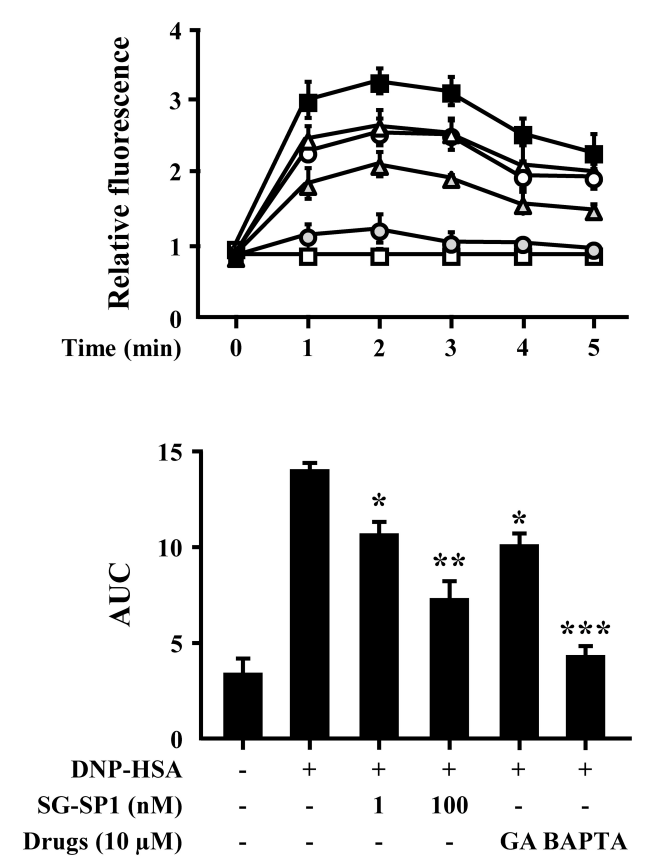

FIGURE 4 | Effects of SG-SP1 on intracellular calcium levels. RBL-2H3 and BMMCs were sensitized with anti-DNP IgE. After incubation overnight, the cells were preincubated with Fluo-3/AM for $1 \mathrm{~h}$, pretreated with or without drugs including SG-SP1, GA, and BAPTA for $1 \mathrm{~h}$, and then challenged with DNP-HSA. Intracellular calcium was measured every $1 \mathrm{~min}$ for 5 min using a fluorescent plate reader. AUC was calculated over 5 min. BAPTA-AM, a calcium chelator, was used as a positive control. Data were presented as the means \pm SEM of three independent experiments. ${ }^{*},{ }^{* *}$, and ${ }^{* \star *}$ indicate statistically significant differences from the DNP-HSA-challenged group at a value of $p<0.05,0.01$, and 0.001 , respectively.

result in death as a result of respiratory obstruction and anaphylactic shock. Asthma-related deaths and emergency department visits for food-induced anaphylaxis have risen steadily over the past couple of decades $(25,26)$. Antihistamines and NSAIDs are prescribed for mild-to-moderate allergic symptoms, and glucocorticoids are used at doses that correspond with the symptom severity $(27,28)$. Despite advances in the management guidelines of allergies, therapeutic alternatives remain unmet because current drugs act as palliatives. Chronic use of glucocorticoids is limited because of its various adverse effects including bruising, muscle weakness, weight gain, skin changes, sleep disturbances, and pathologic fractures (29).

Natural products-originated compounds have been considered safe sources of new drug candidates from decades (30). These compounds could be ameliorated by chemical modifications (31). Epigallocatechin gallate (EGCG), a major component of green tea, is known to have many biologic activities including anti-oxidation, anti-inflammation, and anti-bacterial/viral infections (32-37). GA, a part of EGCG, was shown to have inhibitory effects on mast cell-mediated allergic inflammation in our previous studies, and we have generated various derivatives of GA to improve its pharmacological effectiveness $(10,11)$. As mentioned above, to strengthen the effectiveness of GA, SG-SP1 was designed from GA (12). In this study, we aimed to compare the anti-allergic effects of SG-SP1 with those of GA.

Mast cells are known to be associated with immediatetype hypersensitivity through the release of allergic mediators and cytokines (38). To examine how SG-SP1 hinders allergic inflammation, we performed an in vitro assay for degranulation and cytokine expression in mast cells. Mast cells are key players in IgE-mediated allergic responses because they release allergic mediators such as histamine, lipid-derived mediators, chemokines, cytokines, and growth factors (39). Therefore, mast cells could be a proper target for the development of 

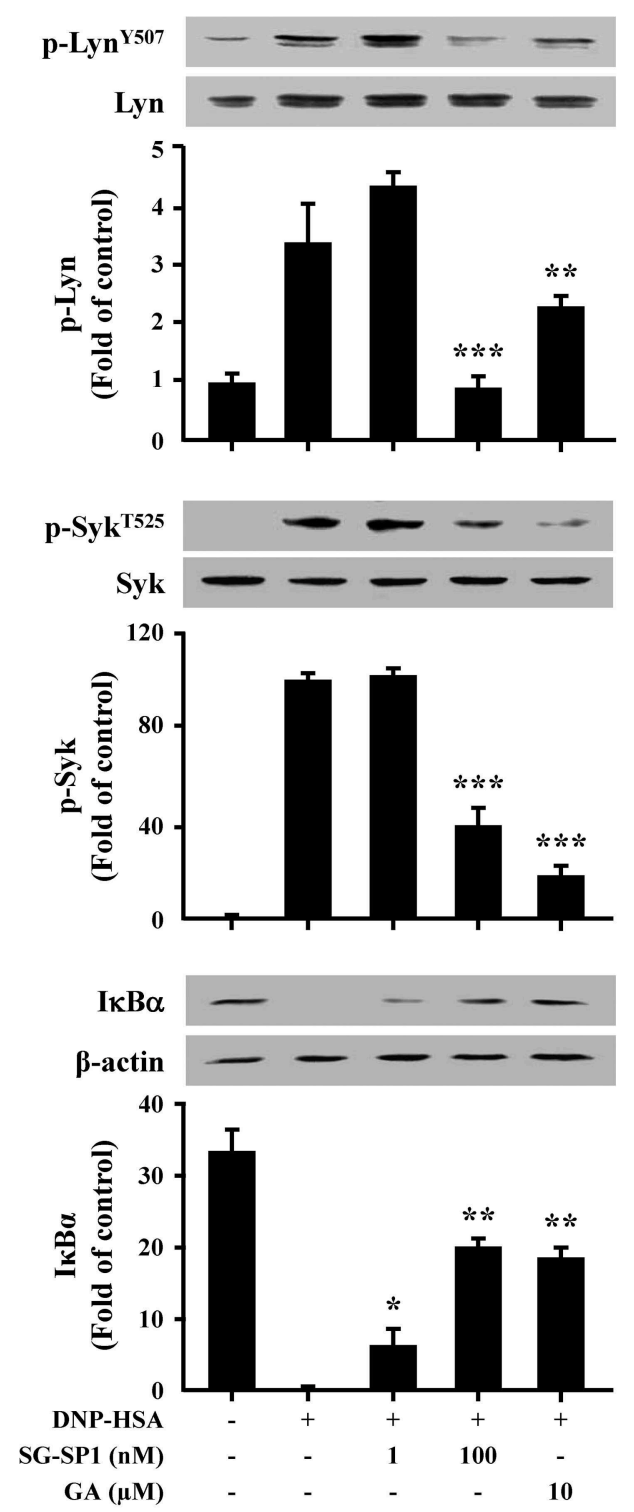
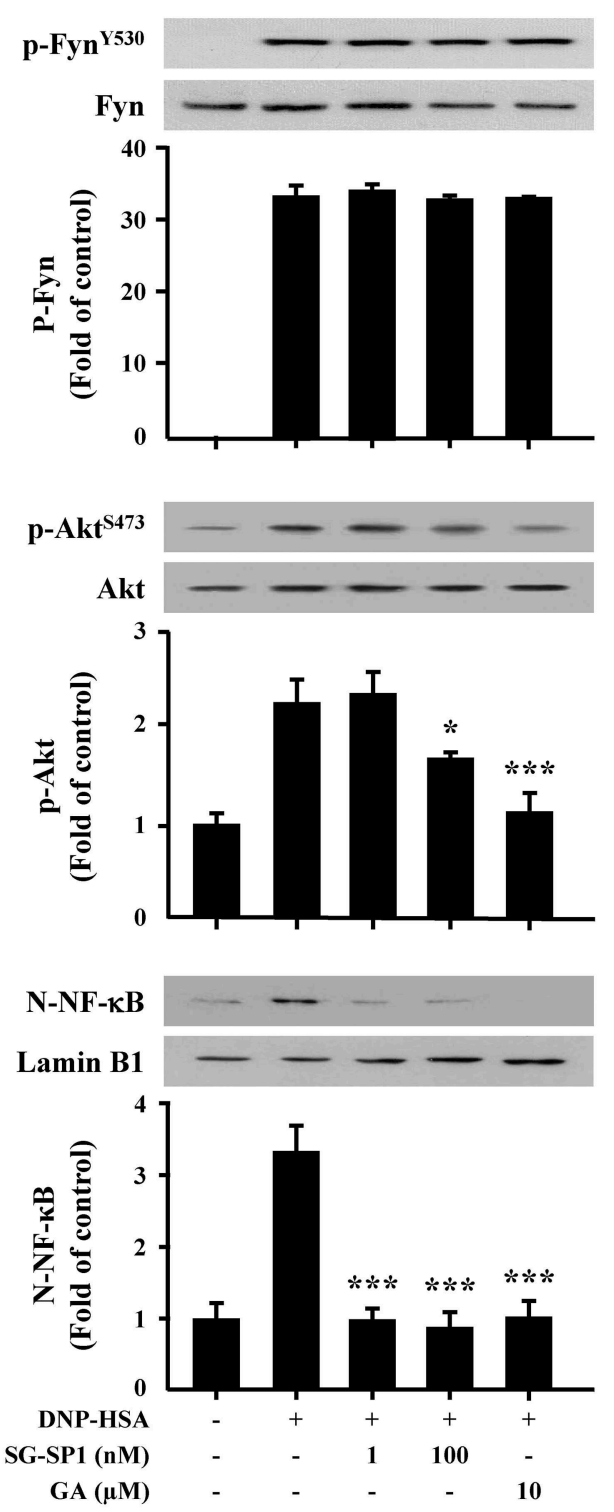

FIGURE 5 | Effects of SG-SP1 on activation of NF-кB, and signaling proteins in mast cells. RBL-2H3 were sensitized with anti-DNP IgE. After incubation overnight, the cells were pretreated with or without SG-SP1 and GA for $1 \mathrm{~h}$ and then challenged with DNP-HSA. Activation of NF-кB and signaling proteins were assayed by Western blot (N-: nuclear, p-: phosphorylated). Lamin B1, $\beta$-actin, and total form of Lyn, Fyn, Syk, and Akt were used as loading controls. The band intensity was quantified and presented as the means \pm SEM of three independent experiments. ${ }^{*},{ }^{* \star}$, and ${ }^{* \star *}$ indicate statistically significant differences from the DNP-HSA-challenged group at a value of $p<0.05,0.01$, and 0.001 , respectively.

therapeutic agents for allergic diseases. Histamine from mast cells results in representative allergic symptoms such as edema, warmth, and erythema (38). Inflammatory cytokines promote and sustain chronic allergy. TNF- $\alpha$ induces an adaptive immune response by activating NF- $\mathrm{B}$ and stimulating the migration, maturation, and differentiation of immune cells $(40,41)$. IL-1 $\beta$ exacerbates autoimmune and allergic diseases including atopic dermatitis, contact hypersensitivity, and bronchial asthma (42). IL-4, which causes plasma B cells to generate IgE, is necessary for an allergic response (43). SG-SP1 reduced the release of histamine and $\beta$-hexosaminidase, as well as the expression of TNF- $\alpha$, IL-1 $\beta$, IL-4, and IL-6. Based on these results, we determined that SG-SP1 could be beneficial to the treatment of allergic diseases.

Mast cell signaling has been researched in detail. Activation of FceRI results in phosphorylation of Lyn and Syk, which stimulate Akt and PLC $\gamma$ (4). PLC $\gamma$ is the key signaling molecule that utilizes the conversion to phosphatidylinositol bisphosphate $\left(\mathrm{PIP}_{2}\right)$ to second messengers, $\mathrm{IP}_{3}$ and diacylglycerol (44). After $\mathrm{IP}_{3}$ binds to its receptors on the surface of the ER, calcium stored in the ER is released into the cytoplasm. Signaling in response to calcium depletion in the ER triggers the rapid influx of extracellular calcium (21). Calcium plays a role of an important secondary messenger in mast cell signaling. The increase in intracellular 
calcium levels induces exocytosis, as well as transcription of histamine and inflammatory cytokine genes (45-47). Our results showed that SG-SP1 reduced calcium influx. Therefore, SGSP1 demonstrated inhibition of mast cell degranulation through calcium blockade and the low level of histamine that results from blocked calcium diminishes the allergic reaction.

To evaluate the anti-allergic mechanisms of SG-SP1, we examined the FceRI-mediated downstream signaling pathway. Lyn, Fyn, Syk, and Akt were chosen as representative signaling proteins, and activations of these proteins were decreased by SG-SP1. Especially, Lyn, a Src family kinase, is an important

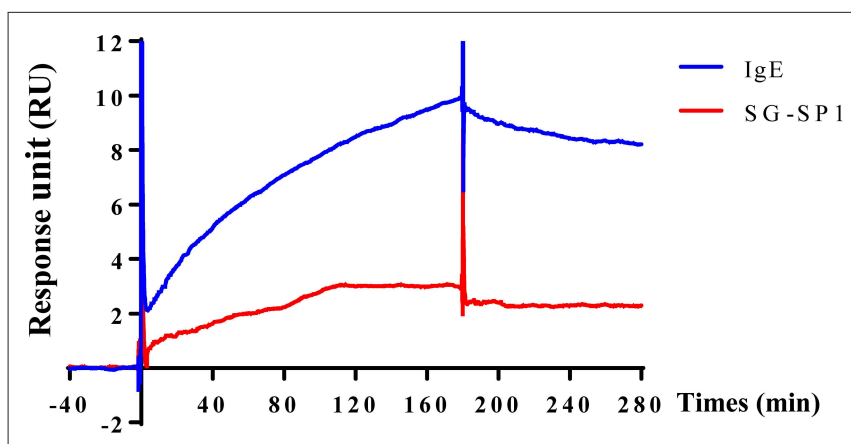

FIGURE 6 | Surface plasmon resonance analysis of SG-SP1 binding to FCeRla. SPR was performed using the CM5 chip containing $\sim 1,300$ response unit FCeRl $\alpha$. SG-SP1 $(100 \mu \mathrm{M})$ was diluted in HBS-EP buffer and flowed at a rate of $30 \mu \mathrm{L} / \mathrm{mL}$ for up to $300 \mathrm{~s}$. SPR sensorgram showed the binding reaction of SG-SP1 like lgE $(100 \mu \mathrm{M})$. SPR characterization of SG-SP1 interaction with $\mathrm{F}_{\mathrm{C} \varepsilon \mathrm{R}} \alpha \mathrm{c}$ compared to $\mathrm{lgE}$, as a positive control. regulator of allergic diseases such as asthma and psoriasis because it binds to FceRI directly (48). As additional study, to determine whether SG-SP1 binds to Fcع RI $\alpha$, IgE-binding region, and where it combines, SPR experiment was performed. We found that both IgE and SG-SP1 bound to FceRI $\alpha$. In our experiment, mast cells were sensitized with anti-DNP IgE before treatment of SG-SP1. This finding recapitulates that IgE binds to FceRI $\alpha$ first, and then SG-SP1 binds to another site. Thus, we assumed that SG-SP1 suppresses mast cell signaling via binding to $\mathrm{Fc \varepsilon RI} \alpha$ at a different region to IgE. These results convinced us that SG-SP1 inhibits the signaling cascade in mast cells by direct binding to FceRI. It should be discussed the role of Fyn during the activation of mast cells. Several report showed that Fyn is vital to mast cell granule trafficking and degranulation $(49,50)$. On the other hand, Barbu et al. showed the limited contribution of Fyn in mast cells (51). In our preliminary experiments, SG-SP1 did not alter IgEstimulated phosphorylation of Fyn. Therefore, we focused on the Lyn activation and downstream signaling pathway in this study. The exact role of Lyn and Fyn in mast cell activation is still debating. However, at least in our experimental condition, SG-SP1 reduced Lyn but not Fyn activation.

We investigated the biologic effects of SG-SP1 using systemic and local anaphylaxis models. These anaphylactic reactions are related to $\mathrm{T}$ helper (Th) 2 responses (52). Mice sensitized with OVA and alum adjuvants showed increased production of Th2

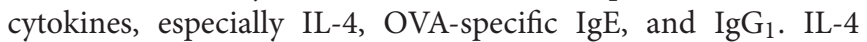
released from antigen-presenting cells differentiates naive $\mathrm{T}$ cells into Th2 cells, which stimulate B cells to produce IgE and $\mathrm{IgG}_{1}$ that bind with FceRI (43). Following challenge to OVA, a sudden increase in serum histamine levels contributed the hypothermia

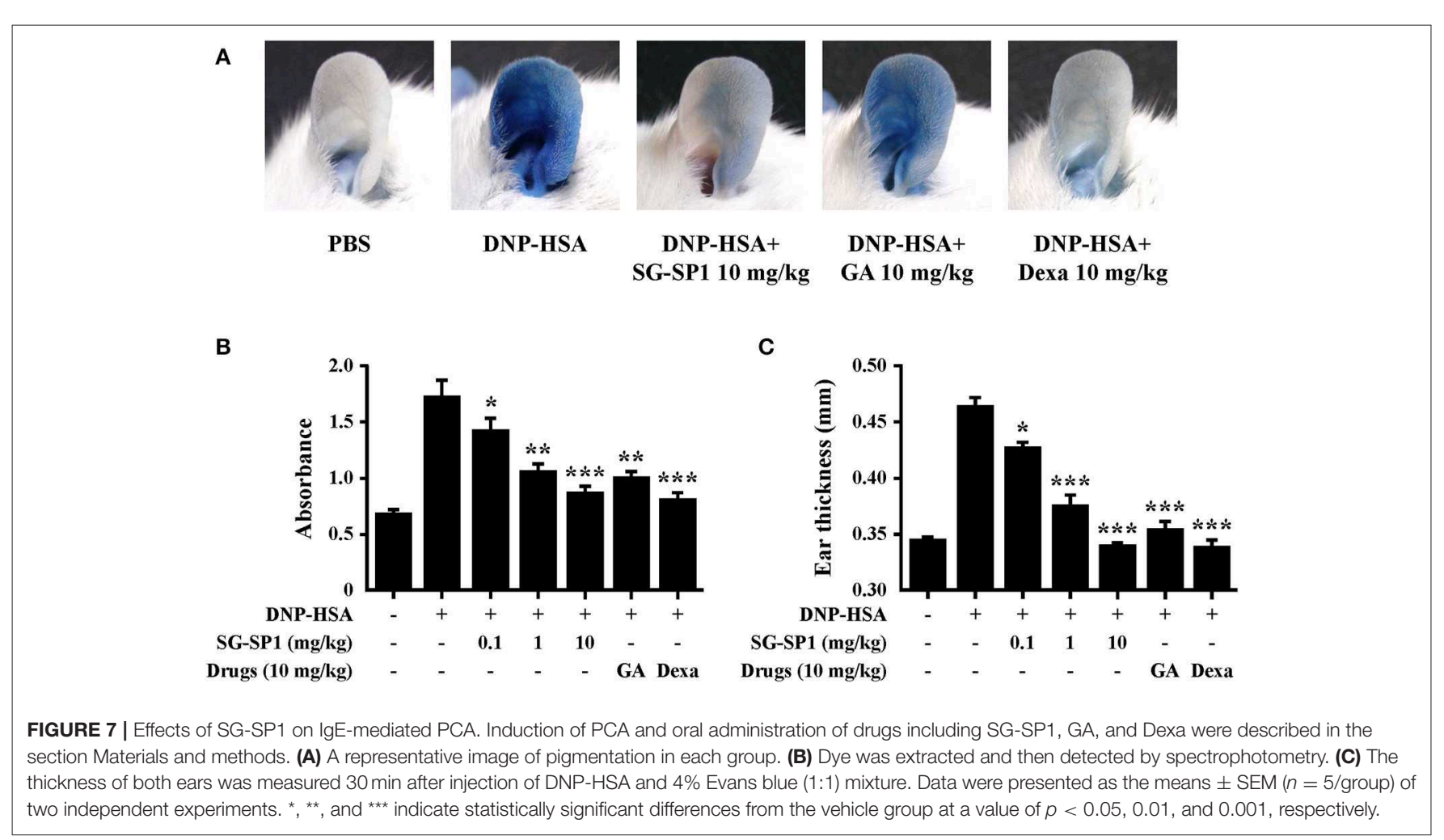


A

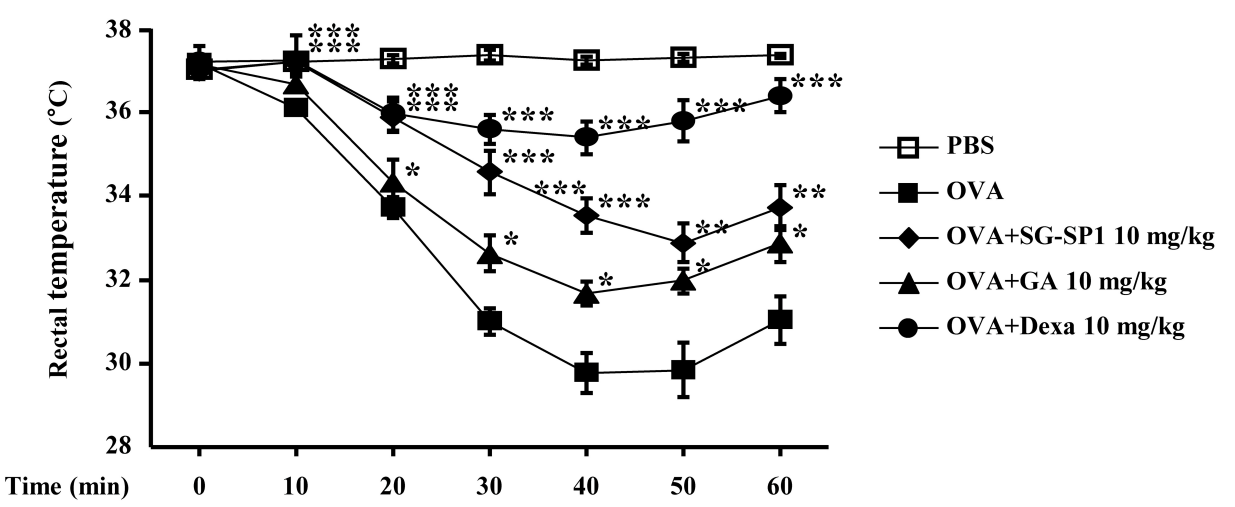

B

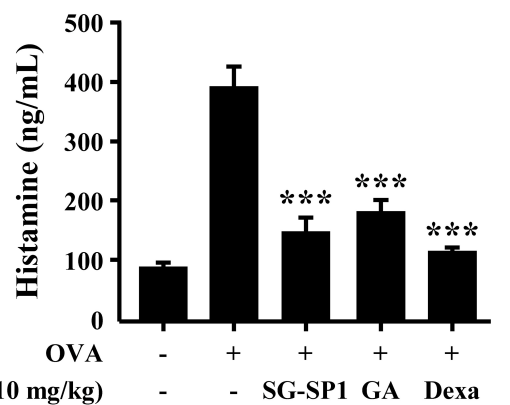

C

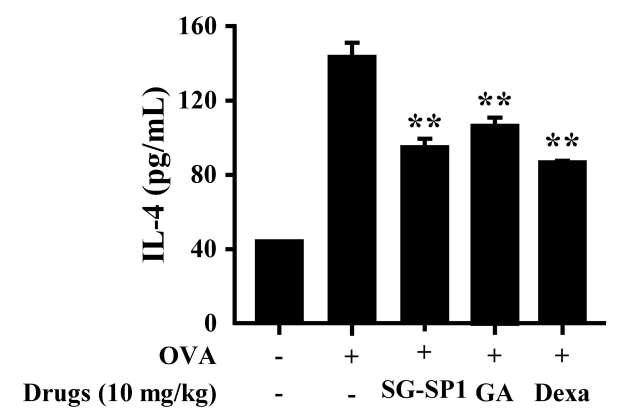

D

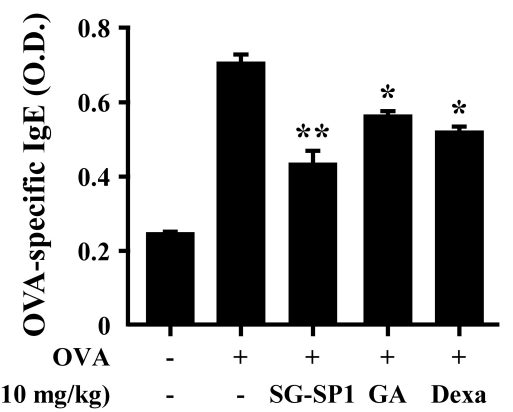

$\mathbf{E}$

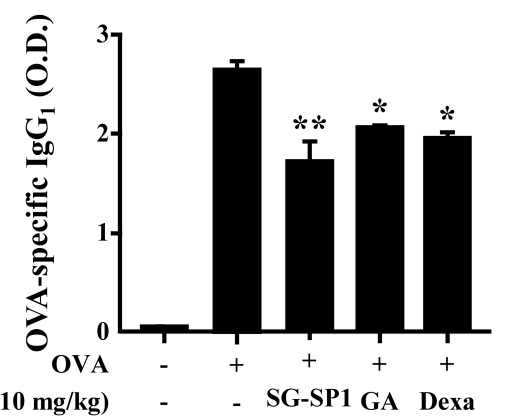

FIGURE 8 | Effects of SG-SP1 on OVA-induced systemic anaphylaxis. Induction of systemic anaphylaxis and oral administration of drugs including SG-SP1, GA, and Dexa were described in the section Materials and Methods. (A) Rectal temperatures were measured every $10 \mathrm{~min}$ for $1 \mathrm{~h}$. Blood was obtained from the abdominal vein of each mouse to measure serum histamine, IL-4, OVA-specific IgE, and OVA-specific lgG levels. (B) Histamine levels were assayed using an o-phthaldialdehyde spectrofluorometric procedure. (C-E) IL-4, OVA-specific IgE, and OVA-specific lgG levels were measured by ELISA. Data were presented as the means \pm SEM $(n=$ 5/group) of two independent experiments. *, **, and ${ }^{\star \star \star}$ indicate statistically significant differences from the vehicle group at a value of $p<0.05,0.01$, and 0.001 , respectively.

in mice (53). Another model, PCA is associated primarily with mast cell degranulation. Pigmentation and ear swelling are caused by histamine, because it enhances vascular permeability (43). We propose that SG-SP1 alleviated anaphylactic symptoms by inhibiting not only the release of histamine from mast cells but also the production of $\mathrm{IgE}$ and $\mathrm{IgG}_{1}$ via reduced IL-4 expression. There is an evidence that IL-4 plays a critical role in allergic sensitization through the production of $\operatorname{IgE}$ and $\operatorname{IgG}_{1}$. As the expression of $\operatorname{IgE}$ and $\operatorname{IgG}_{1}$ was impaired, allergic hypothermia was not observed in IL-4 deficient mice (54). SG-SP1 showed greater suppressive effects of both animal models than those of GA and inhibition equal to that of Dexa in animal models.
Although there have been reports on the anti-allergic effects of GA, its inhibitory mechanism has not been elucidated. Either, the new derivatives were made by supplementing the low metabolic stability of GA. SG-SP1 is designed as an analog based on GA. In the present study, both degranulation of mast cells and expression of inflammatory cytokines were suppressed by SGSP1 and it was associated with the reduction of intracellular calcium levels and NF- $\kappa$ B activation. Mechanically, SG-SP1 inhibited the activation of Lyn/Syk pathway and its downstream signaling molecules to inhibit secretion of allergic mediators. The inhibitory effects result from SG-SP1 binding to FceRI $\alpha$, because SG-SP1 blocked mast cell signaling from Lyn. Thus, we 
confirmed that both IgE and SG-SP1 bound to FcعRI $\alpha$. Therefore, additional studies might be needed to determine the exact binding region of SG-SP1, and to establish what mechanism is effective in inhibiting it after binding. In addition, the inhibitory effects of this mechanism were confirmed in animal models, SGSP1 reduced both systemic and local anaphylaxis by inhibiting the release of allergic mediators. Nevertheless, results of this study provided conclusive evidence that SG-SP1 could be a novel therapeutic candidate to treat the allergic disease.

\section{DATA AVAILABILITY STATEMENT}

The datasets generated for this study are available on request to the corresponding author.

\section{ETHICS STATEMENT}

The animal study was reviewed and approved by Institutional Animal Care and Use Committee of Kyungpook National University.

\section{REFERENCES}

1. Takizawa H. Impact of air pollution on allergic diseases. Korean J Intern Med. (2011) 26:262-73. doi: 10.3904/kjim.2011.26.3.262

2. Larsen JN, Broge L, Jacobi H. Allergy immunotherapy: the future of allergy treatment. Drug Discov Today. (2016) 21:26-37. doi: 10.1016/j.drudis.2015.07.010

3. Beghdadi W, Madjene LC, Benhamou M, Charles N, Gautier G, Launay P, et al. Mast cells as cellular sensors in inflammation and immunity. Front Immunol. (2011) 2:37. doi: 10.3389/fimmu.2011.00037

4. Kalesnikoff J, Galli SJ. New developments in mast cell biology. Nat Immunol. (2008) 9:1215-23. doi: 10.1038/ni.f.216

5. James DR, Lyttle MD. British guideline on the management of asthma: SIGN clinical guideline 141, 2014. Arch Dis Child Educ Pract Ed. (2016) 101:319-22. doi: 10.1136/archdischild-2015-310145

6. Kay AB. Allergy and allergic diseases. First of two parts. N Engl J Med. (2001) 344:30-7. doi: 10.1056/NEJM200101043440106

7. Schmitt J, Stadler E, Kuster D, Wustenberg EG. Medical care and treatment of allergic rhinitis: a population-based cohort study based on routine healthcare utilization data. Allergy. (2016) 71:850-8. doi: 10.1111/all.12838

8. Je IG, Choi HG, Kim HH, Lee S, Choi JK, Kim SW, et al. Inhibitory effect of 1,2,4,5-tetramethoxybenzene on mast cell-mediated allergic inflammation through suppression of IкB kinase complex. Toxicol Appl Pharmacol. (2015) 287:119-27. doi: 10.1016/j.taap.2015.05.006

9. Kim YY, Je IG, Kim MJ, Kang BC, Choi YA, Baek MC, et al. 2-Hydroxy-3methoxybenzoic acid attenuates mast cell-mediated allergic reaction in mice via modulation of the FceRI signaling pathway. Acta Pharmacol Sin. (2017) 38:90-9. doi: 10.1038/aps.2016.112

10. Je IG, Kim HH, Park PH, Kwon TK, Seo SY, Shin TY, et al. SG-HQ2 inhibits mast cell-mediated allergic inflammation through suppression of histamine release and pro-inflammatory cytokines. Exp Biol Med (Maywood). (2015) 240:631-8. doi: 10.1177/1535370214555663

11. Kim SH, Jun CD, Suk K, Choi BJ, Lim H, Park S, et al. Gallic acid inhibits histamine release and pro-inflammatory cytokine production in mast cells. Toxicol Sci. (2006) 91:123-31. doi: 10.1093/toxsci/kfj063

12. Fei X, Je IG, Shin TY, Kim SH, Seo SY. Synthesis of gallic acid analogs as histamine and pro-inflammatory cytokine inhibitors for treatment of mast cell-mediated allergic inflammation. Molecules. (2017) 22:E898. doi: 10.3390/molecules 22060898

13. Hox V, Desai A, Bandara G, Gilfillan AM, Metcalfe DD, Olivera A. Estrogen increases the severity of anaphylaxis in female mice through enhanced

\section{AUTHOR CONTRIBUTIONS}

M-JK, I-GJ, JS, and XF carried out the major experiments and drafted the manuscript. HY, SL, and WK supported in the study design, reviewed the protocol, and participated to interpret the primary outcome. YJ, S-YS, and S-HK supervised the research and co-wrote the manuscript.

\section{FUNDING}

This work was supported by the National Research Foundation of Korea Grant funded by the Korean Government (2016R1 A2B4008513, 2019M3A9H1103690, 2014R1A5A2009242, 2018R 1D1A3A03000686, and 2012M3A9B6055416).

\section{SUPPLEMENTARY MATERIAL}

The Supplementary Material for this article can be found online at: https://www.frontiersin.org/articles/10.3389/fimmu. 2020.00050/full\#supplementary-material

endothelial nitric oxide synthase expression and nitric oxide production. $J$ Allergy Clin Immunol. (2015) 135:729-36 e5. doi: 10.1016/j.jaci.2014.11.003

14. Kim MJ, Kim YY, Choi YA, Baek MC, Lee B, Park PH, et al. Elaeocarpusin inhibits mast cell-mediated allergic inflammation. Front Pharmacol. (2018) 9:591. doi: 10.3389/fphar.2018.00591

15. Bae Y, Lee S, Kim SH. Chrysin suppresses mast cell-mediated allergic inflammation: involvement of calcium, caspase-1 and nuclear factorкB. Toxicol Appl Pharmacol. (2011) 254:56-64. doi: 10.1016/j.taap.2011. 04.008

16. Je IG, Kim DS, Kim SW, Lee S, Lee HS, Park EK, et al. Tyrosol suppresses allergic inflammation by inhibiting the activation of phosphoinositide 3-kinase in mast cells. PLoS ONE. (2015) 10:e0129829. doi: 10.1371/journal.pone.0129829

17. Thangam EB, Jemima EA, Singh H, Baig MS, Khan M, Mathias CB, et al. The role of histamine and histamine receptors in mast cell-mediated allergy and inflammation: the hunt for new therapeutic targets. Front Immunol. (2018) 9:1873. doi: $10.3389 /$ fimmu.2018.01873

18. Fukuishi N, Murakami S, Ohno A, Yamanaka N, Matsui N, Fukutsuji K, et al. Does $\beta$-hexosaminidase function only as a degranulation indicator in mast cells? The primary role of $\beta$-hexosaminidase in mast cell granules. J Immunol. (2014) 193:1886-94. doi: 10.4049/jimmunol.1302520

19. Sismanopoulos N, Delivanis DA, Alysandratos KD, Angelidou A, Therianou A, Kalogeromitros D, et al. Mast cells in allergic and inflammatory diseases. Curr Pharm Des. (2012) 18:2261-77. doi: 10.2174/1381612128001 65997

20. Baba Y, Nishida K, Fujii Y, Hirano T, Hikida M, Kurosaki T. Essential function for the calcium sensor STIM1 in mast cell activation and anaphylactic responses. Nat Immunol. (2008) 9:81-8. doi: 10.1038/ni1546

21. Vig M, DeHaven WI, Bird GS, Billingsley JM, Wang H, Rao PE, et al. Defective mast cell effector functions in mice lacking the CRACM1 pore subunit of store-operated calcium release-activated calcium channels. Nat Immunol. (2008) 9:89-96. doi: 10.1038/ni1550

22. Gasparini C, Feldmann M. NF- $\mathrm{kB}$ as a target for modulating inflammatory responses. Curr Pharm Des. (2012) 18:5735-45. doi: $10.2174 / 138161212803530763$

23. Dhami S, Kakourou A, Asamoah F, Agache I, Lau S, Jutel M, et al. Allergen immunotherapy for allergic asthma: a systematic review and meta-analysis. Allergy. (2017) 72:1825-48. doi: 10.1111/all.13208

24. Jousilahti P, Haahtela T, Laatikainen T, Makela M, Vartiainen E. Asthma and respiratory allergy prevalence is still increasing among Finnish young adults. Eur Respir J. (2016) 47:985-7. doi: 10.1183/13993003.01702-2015 
25. D’Amato G, Vitale C, Molino A, Stanziola A, Sanduzzi A, Vatrella A, et al. Asthma-related deaths. Multidiscip Respir Med. (2016) 11:37. doi: $10.4081 / \mathrm{mrm} .2016 .331$

26. Rudders SA, Arias SA, Camargo CA Jr. Trends in hospitalizations for foodinduced anaphylaxis in US children, 2000-2009. J Allergy Clin Immunol. (2014) 134:960-2. doi: 10.1016/j.jaci.2014.06.018

27. Pollart SM, Compton RM, Elward KS. Management of acute asthma exacerbations. Am Fam Phys. (2011) 84:40-7.

28. Sur DK, Scandale S. Treatment of allergic rhinitis. Am Fam Physician. (2010) 81:1440-6.

29. Ericson-Neilsen W, Kaye AD. Steroids: pharmacology, complications, and practice delivery issues. Ochsner J. (2014) 14:203-7.

30. Newman DJ, Cragg GM. Natural products as sources of new drugs over the 30 years from 1981 to 2010. J Nat Prod. (2012) 75:311-35. doi: $10.1021 / \mathrm{np} 200906 \mathrm{~s}$

31. Barot M, Bagui M, Gokulgandhi MR, Mitra AK. Prodrug strategies in ocular drug delivery. Med Chem. (2012) 8:753-68. doi: 10.2174/157340612801 216283

32. Argentin G, Divizia M, Cicchetti R. Oxidative stress, cytotoxicity, and genotoxicity induced by methyl parathion in human gingival fibroblasts: protective role of epigallocatechin-3-gallate. J Toxicol Environ Health A. (2015) 78:1227-40. doi: 10.1080/15287394.2015.1079582

33. Bai L, Takagi S, Ando T, Yoneyama H, Ito K, Mizugai H, et al. Antimicrobial activity of tea catechin against canine oral bacteria and the functional mechanisms. J Vet Med Sci. (2016) 78:1439-45. doi: 10.1292/jvms.16-0198

34. Hsu S. Compounds derived from epigallocatechin-3-gallate (EGCG) as a novel approach to the prevention of viral infections. Inflamm Allergy Drug Targets. (2015) 14:13-8. doi: 10.2174/1871528114666151022150122

35. Moldovan B, Hosu A, David L, Cimpoiu C. Total phenolics, total anthocyanins, antioxidant and pro-oxidant activity of some red fruits teas. Acta Chim Slov. (2016) 63:213-9. doi: 10.17344/acsi.2015.1421

36. Shin HY, Kim SH, Jeong HJ, Kim SY, Shin TY, Um JY, et al. Epigallocatechin3-gallate inhibits secretion of TNF- $\alpha$, IL- 6 and IL-8 through the attenuation of ERK and NF-кB in HMC-1 cells. Int Arch Allergy Immunol. (2007) 142:33544. doi: 10.1159/000097503

37. Yeoh BS, Aguilera Olvera R, Singh V, Xiao X, Kennett MJ, Joe B, et al. Epigallocatechin-3-gallate inhibition of myeloperoxidase and its counter-regulation by dietary iron and lipocalin 2 in murine model of gut inflammation. Am J Pathol. (2016) 186:912-26. doi: 10.1016/j.ajpath.2015.12.004

38. Galli SJ, Tsai M, Piliponsky AM. The development of allergic inflammation. Nature. (2008) 454:445-54. doi: 10.1038/nature07204

39. Kraft S, Kinet JP. New developments in FceRI regulation, function and inhibition. Nat Rev Immunol. (2007) 7:365-78. doi: 10.1038/nri2072

40. Galli SJ, Tsai M. Mast cells in allergy and infection: versatile effector and regulatory cells in innate and adaptive immunity. Eur J Immunol. (2010) 40:1843-51. doi: 10.1002/eji.201040559

41. Li J, Yin Q, Wu H. Structural basis of signal transduction in the TNF receptor superfamily. Adv Immunol. (2013) 119:135-53. doi: 10.1016/B978-0-12-407707-2.00005-9

42. Krause K, Metz M, Makris M, Zuberbier T, Maurer M. The role of interleukin1 in allergy-related disorders. Curr Opin Allergy Clin Immunol. (2012) 12:47784. doi: 10.1097/ACI.0b013e3283574d0c

43. Galli SJ, Tsai M. IgE and mast cells in allergic disease. Nat Med. (2012) 18:693-704. doi: 10.1038/nm.2755
44. Alsaleh NB, Persaud I, Brown JM. Silver nanoparticle-directed mast cell degranulation is mediated through calcium and PI3K signaling independent of the high affinity IgE receptor. PLOS ONE. (2016) 11:e0167366. doi: 10.1371/journal.pone.0167366

45. Blank U, Cyprien B, Martin-Verdeaux S, Paumet F, Pombo I, Rivera $\mathrm{J}$, et al. SNAREs and associated regulators in the control of exocytosis in the RBL-2H3 mast cell line. Mol Immunol. (2002) 38:1341-5. doi: 10.1016/S0161-5890(02)00085-8

46. Manikandan J, Kothandaraman N, Hande MP, Pushparaj PN. Deciphering the structure and function of FceRI/mast cell axis in the regulation of allergy and anaphylaxis: a functional genomics paradigm. Cell Mol Life Sci. (2012) 69:1917-29. doi: 10.1007/s00018-011-0886-0

47. Tanaka S, Mikura S, Hashimoto E, Sugimoto Y, Ichikawa A. Ca2 ${ }^{+}$influxmediated histamine synthesis and IL- 6 release in mast cells activated by monomeric IgE. Eur J Immunol. (2005) 35:460-8. doi: 10.1002/eji.200425622

48. Ingley E. Functions of the Lyn tyrosine kinase in health and disease. Cell Commun Signal. (2012) 10:21. doi: 10.1186/1478-811X-10-21

49. Parravicini V, Gadina M, Kovarova M, Odom S, Gonzalez-Espinosa C, Furumoto $\mathrm{Y}$, et al. Fyn kinase initiates complementary signals required for IgE-dependent mast cell degranulation. Nat Immunol. (2002) 3:741-8. doi: 10.1038/ni817

50. Nishida K, Yamasaki S, Ito Y, Kabu K, Hattori K, Tezuka T, et al. FceRImediated mast cell degranulation requires calcium-independent microtubuledependent translocation of granules to the plasma membrane. J Cell Biol. (2005) 170:115-26. doi: 10.1083/jcb.200501111

51. Barbu EA, Zhang J, Siraganian RP. The limited contribution of Fyn and Gab2 to the high affinity IgE receptor signaling in mast cells. J Biol Chem. (2010) 285:15761-8. doi: 10.1074/jbc.M110.109413

52. Finkelman FD, Rothenberg ME, Brandt EB, Morris SC, Strait RT. Molecular mechanisms of anaphylaxis: lessons from studies with murine models. $J$ Allergy Clin Immunol. (2005) 115:449-57. doi: 10.1016/j.jaci.2004.12.1125

53. Ishikawa R, Tsujimura Y, Obata K, Kawano Y, Minegishi Y, Karasuyama H. IgG-mediated systemic anaphylaxis to protein antigen can be induced even under conditions of limited amounts of antibody and antigen. Biochem Biophys Res Commun. (2010) 402:742-6. doi: 10.1016/j.bbrc.2010.10.098

54. Chu DK, Mohammed-Ali Z, Jimenez-Saiz R, Walker TD, Goncharova S, LlopGuevara A, et al. T helper cell IL-4 drives intestinal Th2 priming to oral peanut antigen, under the control of OX40L and independent of innate-like lymphocytes. Mucosal Immunol. (2014) 7:1395-404. doi: 10.1038/mi.2014.29

Conflict of Interest: I-GJ was employed by the company ILDONG Pharmaceutical Co. Ltd. JS and HY were employed by the company Daegu-Gyeongbuk Medical Innovation Foundation.

The remaining authors declare that the research was conducted in the absence of any commercial or financial relationships that could be construed as a potential conflict of interest.

Copyright (c) 2020 Kim, Je, Song, Fei, Lee, Yang, Kang, Jang, Seo and Kim. This is an open-access article distributed under the terms of the Creative Commons Attribution License (CC BY). The use, distribution or reproduction in other forums is permitted, provided the original author(s) and the copyright owner(s) are credited and that the original publication in this journal is cited, in accordance with accepted academic practice. No use, distribution or reproduction is permitted which does not comply with these terms. 